Вісник Дніпропетровського університету. Серія: геологія, географія. 2016. 24 (1), 133-138.

Vìsnik Dnìpropetrovs'kogo unìversitetu. Serìa geologîa, geographìâ

Dnipropetrovsk University Bulletin. Series geology, geography. 2016, 24 (1), 133-138.

doi: $10.15421 / 111620$

http://geology-dnu.dp.ua

УДК 911.3+339.5+504.06 (477.63)

\title{
Гірничопромислові території та об’скти Дніпропетровської області як геотуристичні атракції
}

\section{I. М. Суматохіна}

Дніпропетровський національний університет імені Олеся Гончара, Дніпропетровськ, Украӥна, e-mail: Sumatokhina ir@ukr.net

Проведено аналіз ресурсів природного й антропогенного походження для розвитку геотуризму в межах території промислово і техногенно навантаженого регіону - Дніпропетровської області. Складено регіональний каталог гірничопромислових територій та об'сктів як перспективних геотуристичних атракцій промислового регіону. Виконано аналіз територіального розподілу геотуристичних об'єктів. Доведено можливості якісного удосконалення i кількісного розширення ресурсної бази геотуризму за рахунок цікавих гірничопромислових об'єктів різних типів.

Проведено натурні спостереження, геоекологічні дослідження ключових територій та об'єктів природного та антропогенного походження. Дослідження включали збирання, аналіз, узагальнення інформації про території та об'єкти природно-заповідного фонду та гірничопромислові території Дніпропетровської області. Обгрунтовано можливості та перспективи розвитку на території області геотуризму пізнавального, наукового, професійно-ділового, навчального, оздоровчого, спортивного, екстремального спрямування. Визначено соціально-екологічну роль та рекреаційну цінність об'сктів у межах кожного гірничопромислового району з метою збереження георізноманіття та збільшення геотуристичного потенціалу території. Практичне значення виконаних досліджень полягає у створенні регіонального каталогу гірничопромислових територій та об’єктів як геотуристичних атракцій, аналізі їх територіального розміщення з метою формування інформаційного забезпечення геотуристичних трас по території області.

Ключові слова: геотуризм, гірничопромисловий район, геотуристичні атракиії, геотуристичні дестинаиії

\section{Mining Industry territories and objects of Dnipropetrovsk region as geotourist attractions}

\section{I.M.Sumatokhina}

Oles Honchar Dnipropetrovsk National University, Dnipropetrovsk, Ukraine, e-mail: Sumatokhina_ir@ukr.net

The analysis of natural and androgenic geneses resources for development geotourizm was performed within the industrial and technologically loaded region - Dnipropetrovsk region. The regional catalog of mining areas and objects as promising geotourizm industrial area attractions was done. The analysis of spatial distribution geotourist objects. Proven capabilities qualitative improvement and quantitative expansion of the resource base for geotourizm by mining interesting objects of different types.

The observation a full-scale monitoring and geoenvironmental study of key areas and sites of natural and anthropogenic genesis. The study included the collection, analysis, compilation of information about the area and objects of nature preserves and mine territory of the Dnepropetrovsk region. Grounded opportunities and prospects of the region geotourizm educational, scientific, professional and business, educational, health, sports, extreme direction. Defined social and environmental role and recreational value of objects within each mining area for preserve and increase of the geodiversity and geotourizm potential territory. The practical significance of the research is to create a regional directory of mining areas and objects as geotourizm attractions, analyzing their territorial distribution in order to develop information support of geotourizm trails in the area.

Keywords: geotourizm, mining areas, geotourist attractions, geotourist destinations

Вступ. На сьогоднішній день рекреація та туризм стали важливим чинником, який значною мірою впливає на соціально-економічний розвиток як окремих регіонів, так і країни в цілому. В Україні виділяються традиційно рекреаційні регіони, у межах яких досить тривалий час розвиваються різні види туризму на основі використання природних та культурноісторичних ресурсів. Водночас $є$ регіони промислові, 
які характеризуються високим ступенем освоєння i антропогенного перетворення усіх компонентів природного середовища. Дослідження туристичних ресурсів цих регіонів - одне 3 першочергових завдань конструктивно-географічних досліджень, які проводяться з метою визначення шляхів оптимізації використання ресурсної бази, пошуку новітніх напрямків туристичної діяльності та удосконалення територіально-рекреаційних систем на найближчу i віддалену перспективу в інтересах суспільства (Maslyak P. O. 2008).

Дніпропетровська область - один iз старопромислових та найбільш техногенно навантажених регіонів країни. Тому питання розроблення i впровадження програми розвитку туризму на іiі території стає проблемним і перш за все потребує грунтовного аналізу наявної ресурсної бази. Визначення рекреаційної цінності геолого-геоморфологічних ресурсів різного походження сприятиме розширенню як природоохоронних так і територіально-рекреаційних систем, а також розвитку нових видів туризму. Одним з найперспективніших напрямів оптимізації туристичної діяльності є залучення у туристичний процес цікавих для споживача геотуристичних дестинацій антропогенного походження, тобто гірничопромислових.

Використання природних геолого-геоморфологічних об' єктів із туристичною метою висвітлене в численних публікаціях багатьох учених (Е. Т. Палієнко, В. В. Стецюк, Ю. В. Зінько, Я. С. Кравчук, О. М. Шевчук, В. В. Манюк, Вад. В. Манюк та ін.). Науково-методичним обгрунтуванням розвитку туризму на основі антропогенних, у тому числі гірничопромислових, ландшафтів стали праці Ф. М. Мількова, Г. І. Денисика, Ю. Г. Тютюнника, О. О. Любіцевої, В. І. Федотова, В. Л. Казакова та інших. Окреслені проблемні питання розвитку туризму на території Дніпропетровської області на основі залучення гірничопромислових об'єктів вивчали у Криворізькому районі В. Л. Казаков, О. О. Калініченко, О. С. Куліковська, В. С. Пацюк, С. В. Ярков, в інших гірничопромислових районах - О. Г. Шапар, О. О. Скрипник, С. М. Сметана, В. В. Манюк та інші. Існуючий досвід наукових досліджень дає підстави оцінювати перспективи розширення геотуристичного потенціалу за рахунок залучення до туристичного процесу гірничопромислових територій та об'єктів.

Матеріали та методи досліджень. 3 метою виявлення найперспективніших для розвитку геотуризму ресурсів ми провели натурні спостереження, геоекологічні дослідження ключових територій та об' єктів природного та антропогенного походження.
Дослідження включали збирання, аналіз, узагальнення інформації про території та об'єкти природнозаповідного фонду та гірничопромислові території Дніпропетровської області.

Важливим етапом дослідження стало визначення соціально-екологічної ролі й рекреаційної цінності об'єктів, розташованих у межах кожного гірничопромислового району, з метою збереження георізноманіття та збільшення геотуристичного потенціалу території. Цінність геолого-геоморфологічних об'єктів визначали за методикою, запропонованою раніше (Суматохіна I. М., 2006).

Практичне значення виконаних досліджень полягає у створенні регіонального каталогу гірничопромислових територій та об'єктів як геотуристичних атракцій, аналізі їх територіального розміщення 3 метою формування інформаційного забезпечення геотуристичних трас по території області.

Результати та обговорення. Особливість геологогеоморфологічних умов Дніпропетровської області підтверджується складністю i різноманітністю геологічної будови, специфікою формування й розвитку окремих структурно-геологічних елементів та форм природного рельєфу. Регіон розташований в межах Українського щита, Дніпровсько-Донецької западини і Донецької складчастої споруди та зон їх зчленування. Це зумовило різноманіття видів геотуристичних ресурсів та напрямів їх використання.

Аналіз територіального розподілу природних геотуристичних об'єктів здійснено відповідно до переліку територій та об'єктів ПЗФ на основі даних Державного управління охорони навколишнього природного середовища в Дніпропетровській області станом на 01.12.2013 року.

До перспективних об'єктів природного генезису для розвитку геотуризму в Дніпропетровській області можна віднести об'єкти ПЗФ загальнодержавного та місцевого значення різних категорій, зокрема таких як природний заповідник (ДніпровськоОрільський), заповідні урочища («Балка Крутенька», «Гора Калитва»), заказники ландшафтні («Балка Північна Червона», «Богданівський», «Кільченський», «Солоний лиман» та ін.), геологічні пам’ятки природи - визнані, занесені до державного реєстру об'єктів природоохоронного фонду області: еталонні ділянки покладів корисних копалин, місця 3 рідкісними мінеральними асоціаціями (виходи амфіболітів, мігматиту, аркозових пісковиків на території Криворізького ГПР), стратотипи й опорні геологічні розрізи у вигляді природних відслонень («Скелі Мопра»), мальовничий каньйон на р. Кам'янка в Токівських гранітах та ін.). Крім того, перспективними 
геотуристичними об'єктами є опорні геологічні розрізи, розташовані у місцевостях з типовими та різноманітними геолого-геоморфологічними умовами (стратотип четвертинних відкладів у балці Сажавка (інш. - Сажівка, Кам`янувата), відслонення новомосковського горизонту 3 стародавньою фауною біля с. Губиниха) або штучні відслонення гірничих виробок (мандриківські шари із залишками давньої фауни Рибальського кар'єру). Ці об'єкти поки ще не занесені до переліку територій та об'єктів ПЗФ області, але вже залучені до туристичного процесу.

Кількість об'єктів ПЗФ Дніпропетровської області складає 172, кожен 3 яких оцінювався за наявною інформацією (даними спостережень, вербальною, фотографічною, картографічною) (Derzhavne upravlinnya okhorony navkolyshn >oho pryrodnoho seredovyshcha v Dnipropetrovs $>$ kiy oblasti. 2013). Із них визнано понад 80\% перспективними - тобто, такими, які залучені або можуть бути залучені у майбутньому до туристичного процесу (Sumatokhina I. M. 2006). Наприклад, Токівський водоспад охороняється як гідрологічна пам'ятка, однак має значну геологогеоморфологічну та естетичну цінність. Він разом iз неподалік розташованою іншою геологічною пам'яткою природи - «Мальовничим каньйоном на р. Кам'янка в токівських гранітах» - приваблює туристів і тому віднесений до категорії перспективних об' єктів для розроблення геотрас. Інший приклад заплава р. Базавлук, занесена до переліку об'єктів ПЗФ як орнітологічний заказник місцевого значення, однак, наш погляд, вона є перспективним геотуристичним об' єктом, зважаючи на рідкісну для промислового регіону мальовничість та привабливість ландшафтів.

Значна кількість привабливих для туристів геоморфологічних об'єктів Дніпропетровської області - це переважно форми та елементи флювіального рельєфу, іноді ускладнені елементарними формами, що утворились внаслідок розвитку гравітаційних, еолових та акумулятивних процесів. Дуже поширені морфоскульптурні форми рельєфу - долинні, заплавно-терасові, яружні, балкові. Зустрічаються кам'янисті уступи річищ, водоспади, каньйони. Крім того приваблюють туристів унікальні для регіону форми рельєфу - невеликі пороги i каскадний водоспад, утворені з порфіробластових гранітів на р. Кам'янка, або гора Калитва, що утворилась унаслідок складчасто-лускуватих деформацій у периферійній частині льодовика під час дніпровського зледеніння.

Прикладом втрачених об'єктів стали затоплені острови і заплава Дніпра, Кодацький поріг. Ці об’єкти особливо перспективні для розвитку геотуризму науково-освітнього та пізнавального спрямування.
У межах гірничопромислових районів Дніпропетровщини в результаті експлуатації родовищ корисних копалин на території області сформувалися різні види гірничопромислових ландшафтів та об'єктів, які поступово перетворюються на геотуристичні дестинацій. За гірничопромисловий район ми вважаємо територію з підвищеною концентрацією родовищ корисних копалин та підприємств 3 їх видобутку чи обробки, що характеризуються специфічними місцевими геологічними умовами, структурою, проблемами і перспективами розвитку.

Аналіз науково-методичних підходів та принципів економічного та галузевого районування та побудованих на їх основі схем районування території України, запропонованих різними авторами (Ф. Д. Заставний, В. А. Поповкін, О. І. Шаблій, М. М. Паламарчук, В. Нудельман, Я. Сивий) дозволяє виділити на території Дніпропетровської області чотири гірничопромислові райони: Криворізький (разом із Криворізькою агломерацією), Верхньодніпровсьикй, Нікопольсько-Токмацький, Павлоградсько-Петропавлівський. Велика кількість геотуристичних гірничопромислових атракцій сформувались у кожному районі. Вони розміщені по території нерівномірно (рис. 1), а їх загальну кількість важко точно порахувати. Так, В. Л. Казаков тільки на території Криворіжжя виділив 45 шахт, 41 кар'єр, 89 відвалів тощо. В. В. Манюк на всій території Дніпропетровської області зазначає 57 об'єктів і зважаючи на геологічну значущість обгрунтовує їх віднесення до категорії геосайтів.

У ході нашого дослідження складено регіональний каталог гірничопромислових територій (у межax рудних полів) та об'єктів як перспективних геотуристичних атракцій (усього 132), який ще не остаточно сформований і передбачає можливість подальшого уточнення й оновлення. Ці території та об'єкти є складовою ресурсної бази для розвитку геотуризму різного спрямування, а саме пізнавального, професійно-ділового, наукового, навчального, оздоровчого, спортивного (екстремального). Враховуючи досвід попередніх досліджень (H. Rudko, 2008, V. L. Kazakov, 2013, Ye. A. Ivanov, 2014), геотуристичні атракції гірничопромислових районів можна віднести до таких типів:

1) історичні гірничопромислові ландшафти, залишки і свідчення про колишні гірничі об'єкти (старі копальні, давні кар'єри);

2) сучасні гірничопромислові території та об'єкти (шахти, кар' єри, свердловини, ГЗК, ЦЗФ, металургійні заводи, сховища гірничопромислових відходів, ділянки антропогенної трансформації рельєфу, ділян- 


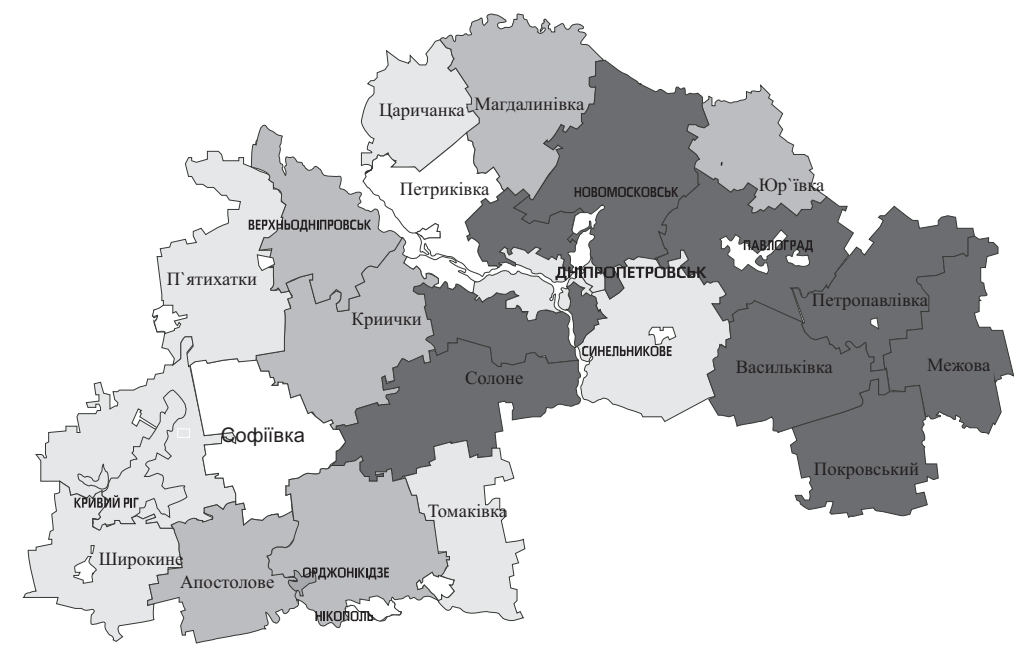
Площа об єктів ПЗФ, перспективних для розвитку геотуризму у межах районів та міст, га

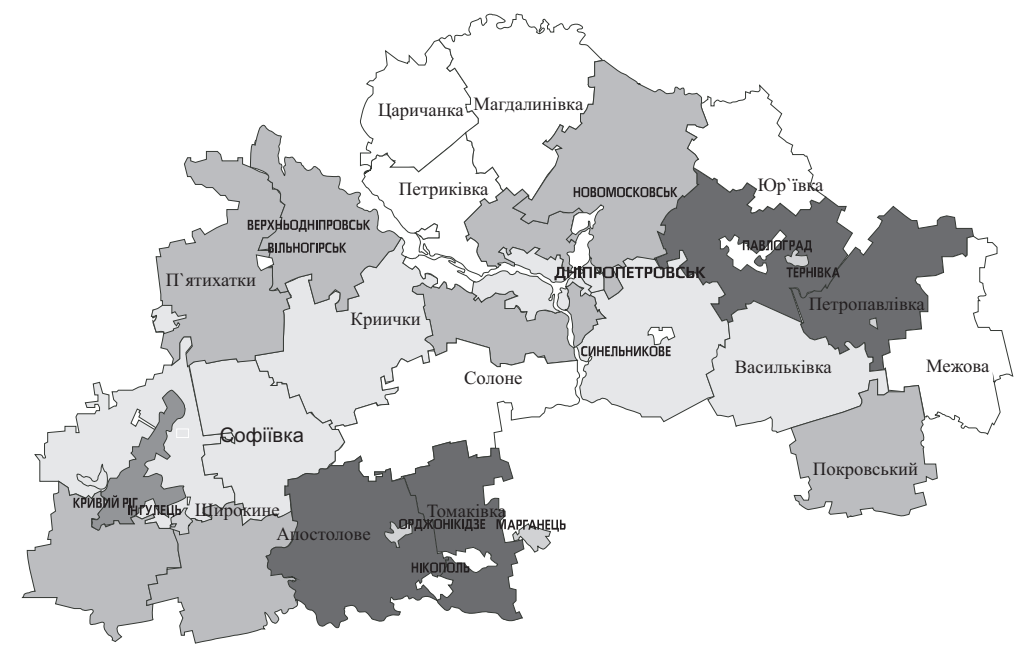
нкопопь міс міста та їх назви
Солоне центри адміністративних районів

понад 3000

1000-3000

$100-1000$

менше 100

відсутні

Площа гірничопромислових об єктів, перспективних для розвитку геотуризму у межах районів та міст, га

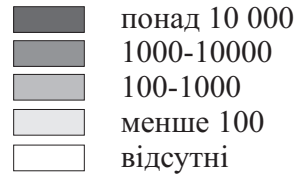

Рис. 1 Перспективні геотуристичні території та об’єкти Дніпропетровської області

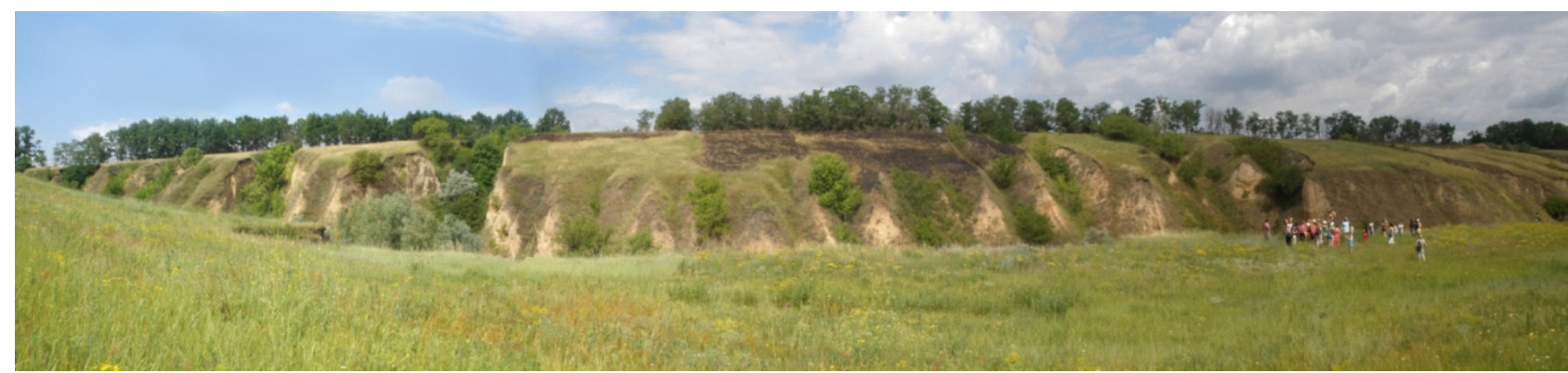

Рис. 2 Студенти геолого-географічного факультету ДНУ ім. Олеся Гончара під час навчальної географічної практики у балці Сажавка, м. Дніпропетровськ

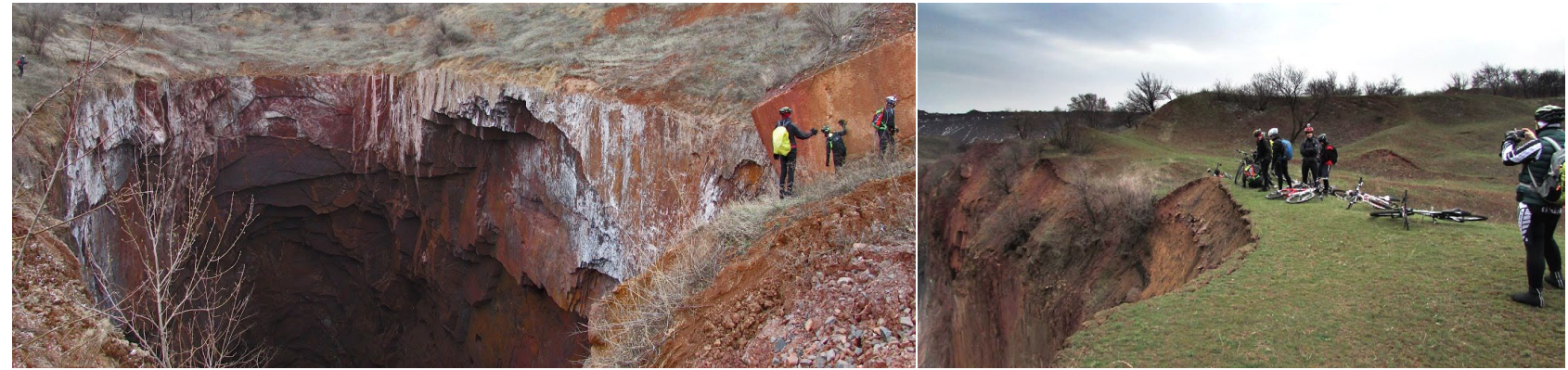

Рис. 3 Гірничопромислові об’єкти у м. Кривий Ріг (фото Р. Обухова) 


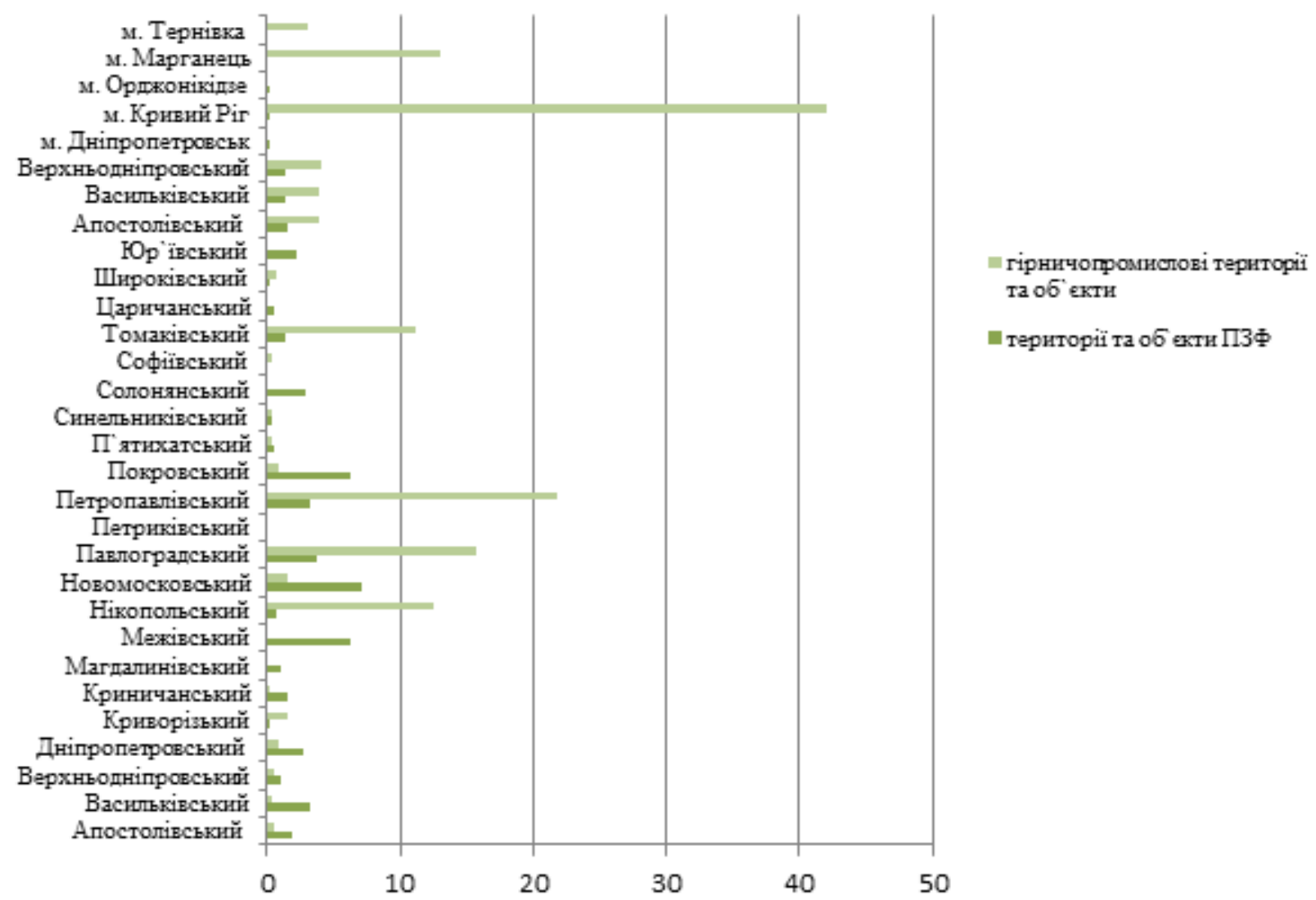

Рис. 4 Перспективні геотуристичні території та об’єкти у межах адміністративних районів та міст Дніпропетровської області (площа, \%)

ки поширення техногенно зумовлених небезпечних екзогенних процесів тощо);

3) культурно-історичні об'єкти, пов'язані 3 гірничими технологіями, історією гірничої справи, виробничою діяльністю та побутом гірників тощо (музеї, шахтарські поселення тощо);

4) постмайнінгові території та об' єкти, утворені за останні 20 років (рекреаційні, природоохоронні).

Поєднання природних та гірничопромислових геотуристичних атракцій 3 історичними, археологічними або історико-культурними територіями і об'єктами є відіграє важливу роль у формуванні геотрас. Так, геотуристичною атракцією бачиться унікальне місце на правому березі Дніпра навпроти острова Чаплі і вже втраченого Кодацького порогу - балка Сажавка та ії найближче оточення. В балці досліджено стратотип антропогенових відкладів України і першу ранньопалеолетичну пам'ятку мустьєрську стоянку. Поряд залишились рештки фортифікаційного рельєфу фортеці Кодак, давнє козацьке поховання, а також старий гранітний кар'єр, що функціонував з 1933 по 1990-ті роки. Значна концентрація різноманітних туристичних об'єктів на локальній ділянці сприяє проведенню як навчальних геологічних, географічних, археологічних маршрутів, так і фольклорних фестивалів (рис.2, 3).

Виконаний просторовий аналіз дозволив виявити асиметричність територіального розподілу геотуристичних об'єктів природного та антропогенного походження по території області (рис.1, 4). Площі природних територій, що охороняються, більші (6-7\%) у межах тих районів області, які не мають значних покладів корисних копалин (наприклад, Новомосковський, Межівський, Покровський). I, навпаки, зменшуються до $0,01-1,0 \%$ у межах регіонів, що характеризуються високим розвитком гірничодобувної промисловості (Криворізький р-н, м. Кривий Ріг, м. Орджонікідзе). Водночас Петриківський, Царичанський та Софіївський райони майже зовсім не мають геотуристичних ресурсів як природного, так і антропогенного походження.

У розрізі адміністративних районів середня площа територій та об'єктів природно-заповідного фонду, у складі яких виділено геотуристичні атракції, та середня площа гірничопромислових територій та об’єктів у відсотковому відношенні відповідно дорівнюють $1,87 \%$, та 3,13\%.

Висновки. Дніпропетровська область має специфічні місцеві геологічні та геоморфологічні особливості, тривалу історію розвитку гірничодобувних галузей, 
що створює передумови формування ресурсної бази для розвитку геотуризму різного спрямування пізнавального, наукового, професійно-ділового, навчального, оздоровчого, спортивного, екстремального. Територіальний розподіл геотуристичних об'єктів характеризується асиметричністю, зумовленою як природними, так і антропогенними чинниками; наявність гірничопромислових об'єктів і території якісно та кількісно позначається на ресурсній базі геотуризму.

\section{Бібліографічні посилання}

Derzhavne upravlinnya okhorony navkolyshn > oho pryrodnoho seredovyshcha v Dnipropetrovs kiy oblasti. Merezha terytoriy ta ob»yektiv pryrodno-zapovidnoho fondu Dnipropetrovs >koyi oblasti (stanom na 1 hrudnya 2013 roku). [State Department of Environmental Protection in the Dnipropetrovsk region. The network of territories and objects of natural reserve fund of Dnepropetrovsk region (as of 1 December 2013)]. Retrieved from http: ecodnepr.dp.ua/index.php/prirodofond/97-info

Dnipropetrovs'ka oblast'. Skhema planuvannya terytoriyi. Tom II. Pryrodno-resursnyy potentsial, stan ta okhorona navkolyshn'oho seredovyshcha, transport, inzhenerna pidhotovka ta zakhyst terytoriyi, inzhenerna infrastruktura, osnovni tekhniko-ekonomichni pokaznyky, dokumenty. Poyasnyuval'na zapyska. [Dnipropetrovsk region. Planning Scheme territory. - Volume II. Natural resource potential, status and protection of the environment, transport, engineering training and protection of territory, engineering infrastructure, the main technical and economic parameters, documents. Explanatory note]. 2009. Kyiv: State Scientific-Research Institute of Urban Design "Diprocity", 125 (in Ukrainian).

Geological Monuments (geosites) of Ukraine: in 4 vol. 2006 -2011. Kyiv: DIA, 280 (in Ukrainian, English).
Ivanov, Ye. A. 2014. Kontseptual'ni zasady heokadastrovoho vyvchennya hirnychopromyslovykh terytoriy ta ob"yektiv [Conceptual framework of geokadastr study of the mining areas and objects]. Materials of the first scientific seminar "Mineral resources in Ukraine. Prospects for investment.". Truskavets, 71-77 (in Ukrainian).

Kazakov, V. L. 2013. Orhanizatsiya industrial'noho turyzmu: systemnyy pidkhid [Organization of industrial tourism, systematic approach]. Industrial tourism: Realities and Prospects: Proceedings of the first International scientificpractical forum. Krivoy Rog, 21-27 (in Ukrainian).

Manyuk, V. 2004. Geological heritage of the southern part of Ukraine. Natural and Cultural landscapes. Proceedings of a conference. Dublin Castle, 93 - 98. (in English).

Maslyak, P. O. 2008. Rekreatsiyna heohrafiya: Navchal'nyy posibnyk. [Recreational geography: Textbook]. Kyiv, Znannya, 343 (in Ukrainian).

Rud'ko, H. I., Sumatokhina, I.M. 2008. Landshafty i rel'yef hirnychopromyslovykh rehioniv yak ob"yekty spadshchyny [The landscapes and relief mining regions as heritage sites]. Industrial heritage in culture and landscape: Proceedings of the Third International Conference. Krivoy Rig: Publishing House, 199-207 (in Ukrainian). Syvyy, Ya. 2014. Rayonuvannya terytoriyi Ukrayiny za mineral'nymy resursamy [Zoning of Ukraine on mineral resources]. Economic and social geography. - Scientific note, 1, 85-100 (in Ukrainian).

Skrypnik, O. O. 2011. Iyerarkhichna systema ekokorydoriv yak funktsional'na osnova rehional'noyi ekomerezhi Dnipropetrovs'koyi oblasti. [The hierarchical system of ecological corridors as the functional basis for regional ecological network Dnipropetrovsk region]. 14, 86-101 (in Ukrainian).

Sumatokhina, I. M. 2006. Tsinnist' ta ekolohichna bezpeka ob 'yektiv heolohichnoyi spadshchyny [The value and ecological safety of geological heritage objects]. Ecology and Environmental Safety. 4 (34), 83-87 (in Ukrainian). 